\title{
In vitro evaluation of different fungicides against Colletotrichum gloeosporioides causing anthracnose of pomegranate
}

\author{
N.M. JAGTAP ${ }^{1}$, C.V. AMBADKAR ${ }^{1}$ AND G.A. BHALERAO* \\ Department of Agronomy, Vasantrao Naik Marathwada Krishi Vidyapeeth, PARBHANI (M.S.) INDIA \\ (Email : gajubhalerao278@gmail.com)
}

\begin{abstract}
In vitro evaluation of new synthetic fungicides against Colletotrichum gloeosporioides were carried out in the Department of Plant Pathology, College of Agriculture, Osmanabad during the year 2011-12. Among the non-systemic fungicides at 0.3 per cent concentration carbendazim + mancozeb showed 82.10 per cent inhibition of mycelial growth of fungus followed by chlorothalonil with 75.80 per cent and least inhibition of mycelial growth was recorded in captan 63.48 per cent. The systemic fungicides were evaluated against the pathogen at $0.05,0.1,0.15$ per cent concentration. Among these concentration all fungicides were significantly found superior at 0.15 per cent concentration compared to 0.1 and 0.05 per cent concentration. The maximum per cent inhibition of growth of $C$. gloeosporioides was observed in propiconazole (74.86\%) followed by benomyl (68.17\%), iprodion + carbendezim (67.67\%), thiophynate methyl (64.97\%). The least per cent inhibition of fungus was recorded in bittertanol (44.12\%) and hexaconazole (32.62\%).
\end{abstract}

Key Words : Colletotrichum gloeosporioides, Fungicides, Anthracnose, Pomegranate

View Point Article : Jagtap, N.M., Ambadkar, C.V. and Bhalerao, G.A. (2015). In vitro evaluation of different fungicides against Colletotrichum gloeosporioides causing anthracnose of pomegranate. Internat. J. agric. Sci., 11 (2) : 273-276.

Article History : Received : 23.02.2015; Revised : 18.05.2015; Accepted : 25.05.2015

\footnotetext{
* Author for correspondence

${ }^{1}$ College of Agriculture, OSMANABAD (M.S.) INDIA
} 